\title{
Analisis Pengaruh Kedalaman Elektrode Pentanahan dengan Menggunakan Metode Wenner dan Driven Rod
}

Jusi Arnando ${ }^{1}$, Haerul Pathoni ${ }^{1}$, dan Dasrinal Tessal ${ }^{1}$

Program Studi Teknik Elektro, Fakultas Teknik, Universitas Jambi, Indonesia

Email: jusiarnando71@gmail.com, haerul.pathoni@gmail.com, dasrinaltessal@unja.ac.id

\section{Info Artikel}

Diterima: 24 Juni 2020

Disetujui: 5 Agustus 2020

Dipublikasikan: 26 Agustus 2020

\section{Alamat Korespondensi: jusiarnando71@gmail.com \\ Copyright (c) 2020 Jurnal Engineering}

This work is licensed under the Creative Commons Attribution International License (CC BY 4.0).

\begin{abstract}
Abstrak
Pentanahan merupakan salah satu faktor penting dalam menjaga sistem tenaga listrik untuk memperoleh keamanan, keselamatan peralatan, keselamatan lingkungan, maupun orang yang ada di sekitarnya. Untuk mencapai tujuan tersebut diharapkan sistem pentanahan harus mengikuti standar serta persyaratan yang berlaku. Akan tetapi, dalam hal ini sering terjadi penyimpangan hal-hal yang berkaitan erat dengan standar tersebut seperti kedalaman pemasangan pasak/elektrode pentanahan sehingga mengakibatkan nilai tahanan pentanahan tidak mencapai $\leq 5 \Omega$ sesuai dengan yang dipersyaratkan dalam PUIL 2000. Tujuan dari penelitian ini adalah menganalisa pengaruh kedalaman elektrode yang divariasikan kedalamannya serta membandingkan antara metode Wenner dan Driven rod manakah yang menghasilkan tahanan pentanahan yang kecil dengan menggunakan metode penelitian kuantitatif. Hasil penelitian menunjukkan bahwa pengaruh kedalaman elektrode cukup efektif dalam menurunkan tahanan pentanahan dengan nilai tahanan pentanahan untuk metode Driven rod dengan kedalaman 1 meter adalah $94,9 \Omega, 1,25$ meter adalah $77,1 \Omega$, dan 1,5 meter adalah $56 \Omega$. Sedangkan metode Wenner didapatkan kedalaman 1 meter adalah $72,14 \Omega, 1,25$ meter adalah $53,37 \Omega$, dan 1,5 meter adalah 31,48 $\Omega$. Berdasarkan data tersebut maka diperoleh bahwa metode Wenner lebih efektif menurunkan nilai tahanan pentanahan dengan nilai tahanan pentanahan lebih kecil dibandingkan metode Driven rod.
\end{abstract}

Kata kunci : Tahanan pentanahan, Kedalaman, Metode Driven rod, Metode Wenner

\section{Pendahuluan}

Sistem pentanahan mulai dikenal pada awal tahun 1900. Sebelumnya sistem tenaga listrik tidak memakai sistem pentanahan hal ini dikarenakan tegangan listrik masih kecil dan tidak membahayakan. Namun untuk masa sekarang ini sistem-sistem tenaga listrik makin berkembang semakin besar dengan tegangan yang semakin tinggi dan jarak jangkauan semakin luas. Barulah sekarang untuk sistem tenaga listrik memakai sistem pentanahan untuk mengatasi gangguan baik itu konsleting maupun gangguan 
terhadap petir. Kalau tidak, hal ini biasa menimbulkan potensi bahaya listrik yang sangat tinggi, baik bagi manusia, peralatan dan sistem pelayannya sendiri. (Hutahuruk, 1991)

Pemasangan elektrode pentanahan dapat dilakukan dengan cara vertikal (tegak lurus/rod) maupun secara horisontal (sejajar/grid) dengan tanah. Pada pentanahan, elektrode pentanahan ditanam kedalam tanah pada kedalaman tertentu guna memperoleh tahanan pentanahan yang diizinkan. Besar kecilnya nilai tahanan pentanahan sangat tergantung pada kedalaman pasak/elektrode, jenis elektrode dan jenis tanah tempat dimana elektrode tersebut dipasang, sedangkan tanah mempunyai tahanan jenis yang sangat bervariasi di berbagai tempat tergantung dari jenis tanah, lapisan tanah, kelembaban tanah dan temperatur tanah. Tahanan tanah juga dipengaruhi oleh kandungan elektrolit di dalam tanah tersebut, nilai tahanan pentanahan akan semakin bagus atau kecil nilainya jika kedalaman elektrode semakin dalam. (Hutahuruk, 1987). Untuk mendapatkan nilai resistansi pembumian yang kecil sangatlah sulit, hal ini karena nilai resistansi pembumian dipengaruhi oleh beberapa faktor diantaranya resistansi electrode itu sendiri, jenis tanah, jenis elektrode pembumian, suhu dan kelembapan, temperatur tanah, dan kandungan elekrolit. Salah satu faktor yang akan dibahas dalam penelitian ini adalah apa pengaruh nilai tahanan pentanahan jika elektrode ditanam dengan kedalaman yang bervariasi dan seberapa bagus nilai pentanahan jika elektrode batang ditanam di jenis tanah liat dan membandingkan antara dua metode yaitu metode Wenner dan Driven rod, manakah diantara kedua metode tersebut yang menghasilkan nilai tahanan pentanahan yang kecil.

\section{Landasan Teori}

\subsection{Tahanan jenis tanah}

Tahanan jenis tanah sangat menentukan nilai tahanan pentanahan dari elektrode-elektrode pentanahan. Tahanan jenis tanah diberikan dalam satuan Ohm meter yang menentukan tahanan jenis tanah ini tidaklah hanya tergantung pada jenis tanah saja melainkan dipengaruhi oleh kelembapan, kandungan mineral yang dimiliki dan suhu (suhu tidak berpengaruh bila di atas titik beku air) (Hutahuruk d. , 1987). Oleh karena itu, tahanan jenis tanah bisa berbeda-beda dari satu tempat dengan tempat yang lain tergantung dari sifat-sifat yang dimilikinya. Sebagai pedoman kasar, tabel berikut ini berisikan tahanan jenis tanah yang ada di Indonesia (Sumardjati, 2008)

Tabel 1 Tahanan jenis berbagai macam tanah dan tahanan penatanahannya

\begin{tabular}{|c|c|c|}
\hline No. & Jenis tanah & Tahanan jenis tanah $(\Omega-\mathrm{m})$ \\
\hline 1. & Tanah yang mengandung air garam & $5-6$ \\
\hline 2. & Tanah rawa & 30 \\
\hline 3. & Tanah liat & 200 \\
\hline 4. & Pasir tanah & 500 \\
\hline 5. & Batu-batu kerikil basah & 1000 \\
\hline 6. & Batu dan pasir kerikil kering & 3000 \\
\hline 7. & Tanah berbatu & 200 \\
\hline
\end{tabular}




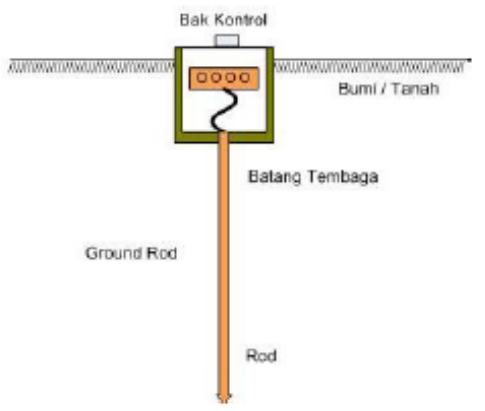

Gambar 1 Elektrode Batang

\subsection{Elektrode Batang}

Elektrodea Batang (Rod), Elektrode batang ialah elektrode dari pipa besi, baja profil, atau batang logam lainnya yang dipancangkan ke dalam tanah. Elektrodea ini merupakan elektrodea yang pertama kali digunakan dan semua teori-teori tentang pentanahan berawal dari elektrodea jenis ini. Elektrodea ini banyak digunakan di gardu induk-gardu induk, Secara teknis elektrodea batang ini sangat mudah untuk pemasangannya yaitu dengan memancangkannya ke dalam tanah. Disamping itu, elektrodea ini tidak memerlukan lahan yang luas. Gambar 1 menunjukan contoh dari elektrodea batang. (Waluyanti, 2008)

Rumus tahanan pentanahan untuk elektrode batang tunggal :

$$
R=\frac{\rho}{2 \cdot \pi \cdot L}\left\{\ln \frac{4 \cdot L}{a}-1\right\}
$$

dimana :

$$
\begin{aligned}
& R_{G}=\text { tahanan pentanahan }(\Omega) \\
& R_{R}=\text { tahanan pentanahan untuk batang tunggal }(\Omega) \\
& \rho=\text { tahanana jenis tanah }(\Omega \mathrm{m}) \\
& L_{R}=\text { panjang elektrode }(\mathrm{m}) \\
& A_{R}=\text { diameter elektrode }(\mathrm{m})
\end{aligned}
$$

\subsection{Metode Driven rod}

Metode Driven Rod (tiga pancangan) atau Metode Fall of Potential cocok digunakan dalam keadaan normal, seperti garis transmisi pada sistem pembumian atau permasalahan dalam area, kesemuanya ini disebabkan karena pemasangan yang dangkal, kondisi tanah, penempatan pengukuran area dan tidak samanya jenis tanah pada dua lapisan tersebut. Metode Driven Rod ditunjukkan seperti Gambar 2. 


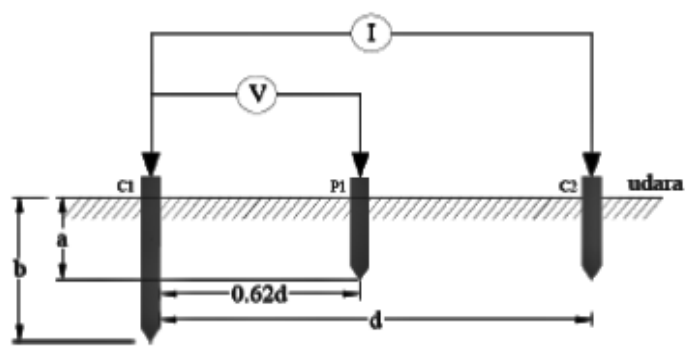

Gambar 2 Metode Driven rod

Rumus metode driven rod sebagai berikut :

$$
\rho=\frac{2 \pi L \cdot R t}{\left(\left(\ln \frac{4 L}{a}\right)-1\right)}
$$

dimana :

$$
\begin{aligned}
\mathrm{Rt} & =\text { tahanan elektrode terukur }(\mathrm{Ohm}) \\
\rho & =\text { tahanan jenis elektrode }(\mathrm{Ohm}-\mathrm{m}) \\
\mathrm{L} & =\text { Panjang elektrode }(\mathrm{m}) \\
\mathrm{a} & =\text { jari-jari penampang elektrode }(\mathrm{m})
\end{aligned}
$$

\subsection{Metode Wenner}

Konfigurasi Wenner merupakan salah satu konfigurasi dalam ekplorasi geofisika dengan susunan elektrode terletak dalam satu garis yang simetris terhadap titik tengah. Konfigurasi elektrode Wenner memiliki resolusi vertikal yang bagus, sensitivitas terhadap perubahan lateral yang tinggi tapi lemah terhadap penetrasi arus terhadap kedalam. Susunan Metode Wenner dapat ditunjukkan seperti Gambar 3.

Konfigurasi Wenner digunakan pada jarak yang sama antara electrode, Pada konfigurasi ini, jarak antar elektrode (a) harus seragam untuk setiap pengukuran dikategorikan sebagai Metode Wenner Alfa.Susunan ini sangat cocok dan efisien untuk mengetahui perbandingan tegangan yang masuk per unitnya dari arus yang mengalir.Pada kondisi yang tidak baik seperti, tanah kering atau tanah padat membutuhkan waktu yang lama untuk mengetahui kontak tahanan antara elektrode dengan tanah.Tahanan Jenis Tanah dengan metode Wenner Alfa dapat dihitung dengan persamaan di bawah ini. (Salamena, 2018).

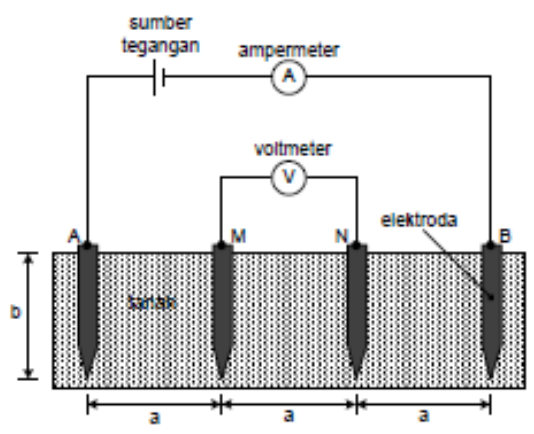

Gambar 3 Metode Wenner 
Metode wenner dapat dilihat pada rumus sebagai berikut:

$$
\rho=\frac{4 \pi a R}{1+\frac{2 a}{\sqrt{a^{2}+4 b^{2}}} \frac{a}{\sqrt{a^{2}+b^{2}}}}
$$

dimana :

$$
\begin{aligned}
\rho & =\text { tahanan jenis tanah }(\Omega \cdot \mathrm{m}) \\
\mathrm{R} & =\text { tahanan yang terukur }(\Omega) \\
\mathrm{a} & =\text { jarak antara elektrode }(\mathrm{m}) \\
\mathrm{b} & =\text { elektrode yang tertanam }(\mathrm{m}) \text { (Hunia yang, 2001) }
\end{aligned}
$$

\section{Metode Penelitian}

Metode yang digunakan dalam melaksanakan penelitian ini adalah metode eksperimen dengan metode kuantitatif berupa metode studi kepustakaan, merupakan metode guna mengkaji teori yang dibutuhkan dari buku-buku referensi untuk menunjang dan berhubungan dengan judul tugas akhir yang diambil. Diskusi, melakukan tanya jawab dengan dosen pembimbing, dan orang orang yang berkompeten didalam bidangnya.Studi lapangan, merupakan metode untuk mengambil data dan mengumpulkan data secara langsung dari tempat objek penelitian, dimana pengambilan data dilakukan dengan cara observasi yaitu mengamati secara langsung untuk mendapatkan data-data yang lebih akurat.

\subsection{Flowchart Penelitian}

Objek dari penelitian ini adalah menghitung besarnya tahanan pentanahan jika elektrode pentanahan di tanam pada kedalaman yang bervariasi yaitu $1 \mathrm{~m}, 1,25 \mathrm{~m}$, dan 1,5 $\mathrm{m}$. Yang kedua yang menjadi objek penelitian adalah membandingkan antara dua metode yaitu metode Driven rod dan Wenner, di antara kedua metode tersebut yang manakah yang mempunyai nilai tahanan pentanahan yang kecil.

\subsection{Waktu dan Tempat Penelitan}

Penelitian dilakukan selama 7 hari di perumahan Puri Angsa 2 mulai tanggal 13 Januari-19 Januari 2020, yang dilakukan pada pagi hari mulai pukul 08:00 sampai dengan pukul 09:00. tepatnya pada koordinat $1^{0} .40^{\prime} 23^{\prime \prime} S 103^{0} .35^{\prime}-8$ ”E pada Google Maps/Earth. Berikut adalah foto lokasi yang diambil dari aplikasi Google Earth. Peneliti memilih lokasi ini karena tanah yang terdapat pada lokasi tersebut cocok dengan tanah yang akan dilakukan penelitian yaitu tanah berjenis tanah liat. 


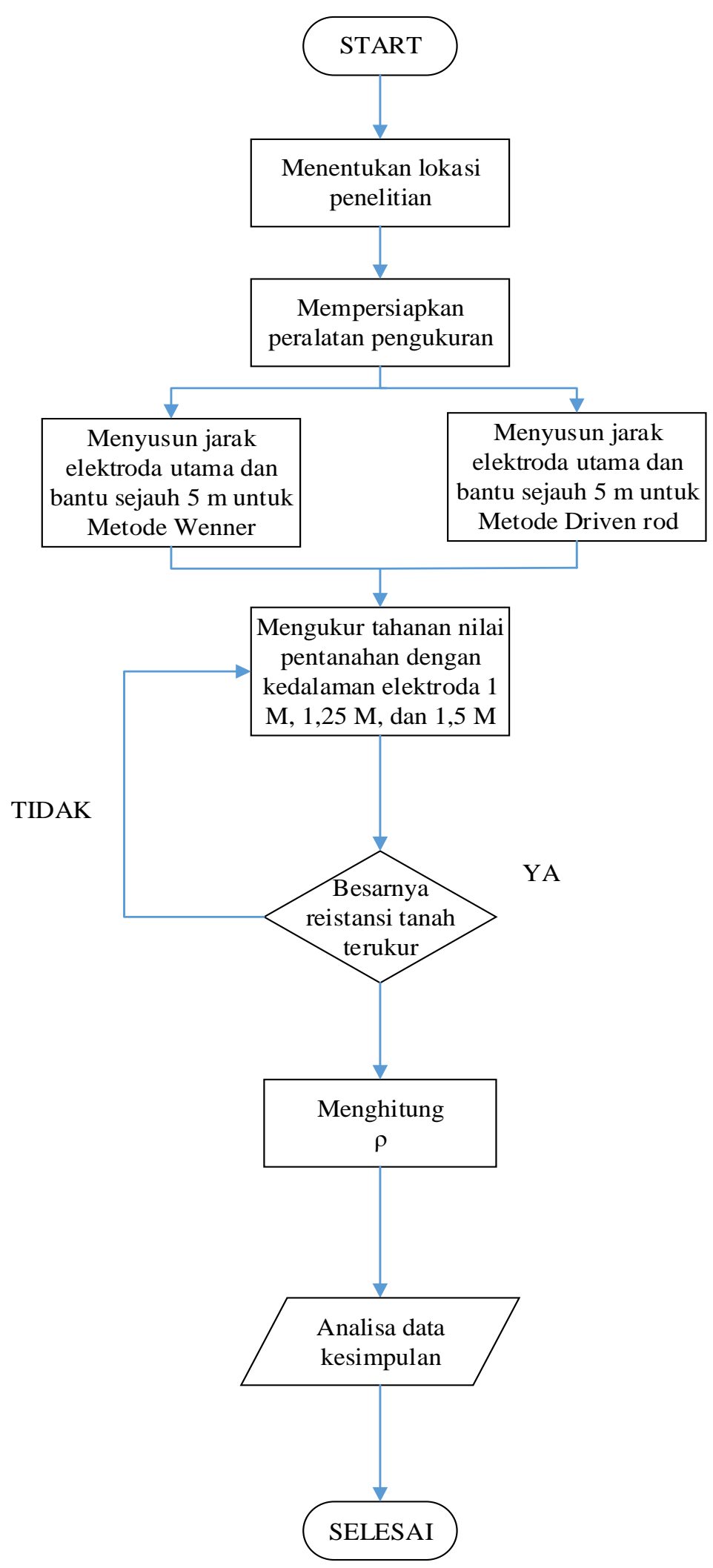

Gambar 4 Flowchart Penelitian 


\section{Hasil Penelitian dan Pembahasan}

\subsection{Data Hasil Pengukuran}

Pengukuran ini dilakukan dengan menggunakan metode Driven rod, untuk alat pengukuran menggunakan alat ukur earth tester. Elektrode yang digunakan adalah elektrode batang dengan diameter $1,6 \mathrm{~cm}$ dan mempunyai panjang 1,5 meter. Pengukuran dilakukan selama 7 hari, dengan waktu pengukuran antara jam 08.00-09.00 dengan alat earth tester dan didapatkan data sebagai berikut:

Tabel 2 Hasil pengukuran tahanan pentanahan dengan metode Driven rod

\begin{tabular}{cccc}
\hline Hari & \multicolumn{3}{c}{ Hasil pengukuran tahanan tanah } \\
& \multicolumn{3}{c}{ (ohm) } \\
\cline { 2 - 4 } & $\begin{array}{c}\text { Kedalaman } \\
1 \text { meter }\end{array}$ & $\begin{array}{c}\text { Kedalaman } \\
1,25 \text { meter }\end{array}$ & $\begin{array}{c}\text { Kedalaman } \\
1,5 \text { meter }\end{array}$ \\
\hline $\mathbf{1}$ & 188,6 & 104,0 & 76,5 \\
\hline $\mathbf{2}$ & 102,0 & 92,3 & 53,7 \\
\hline $\mathbf{3}$ & 66,0 & 44,4 & 24,1 \\
\hline $\mathbf{4}$ & 98,9 & 89 & 80,6 \\
\hline $\mathbf{5}$ & 80,6 & 59 & 35 \\
\hline $\mathbf{6}$ & 88,4 & 53,7 & 46,1 \\
\hline $\mathbf{7}$ & 88,4 & 53,7 & 46,1 \\
\hline $\begin{array}{c}\text { Rata- } \\
\text { rata }\end{array}$ & 94,9 & 77,1 & 56 \\
\hline
\end{tabular}

Tabel 3 Hasil pengukuran tahanan pentanahan dengan metode Wenner

\begin{tabular}{cccc}
\hline Hari & \multicolumn{3}{c}{ Hasil pengukuran tahanan tanah } \\
& \multicolumn{3}{c}{ (ohm) } \\
\cline { 2 - 4 } & $\begin{array}{c}\text { Kedalaman } \\
1 \text { meter }\end{array}$ & $\begin{array}{c}\text { Kedalaman } \\
1,25 \text { meter }\end{array}$ & $\begin{array}{c}\text { Kedalaman } \\
1,5 \text { meter }\end{array}$ \\
\hline $\mathbf{1}$ & 98,0 & 76,5 & 48 \\
\hline $\mathbf{2}$ & 97,3 & 59 & 37 \\
\hline $\mathbf{3}$ & 47,0 & 33,5 & 17,7 \\
\hline $\mathbf{4}$ & 70,7 & 52,9 & 33,4 \\
\hline $\mathbf{5}$ & 65,5 & 51,0 & 31,9 \\
\hline $\mathbf{6}$ & 66,0 & 53,7 & 27,2 \\
\hline $\mathbf{7}$ & 60,5 & 47 & 25,2 \\
\hline $\begin{array}{c}\text { Rata- } \\
\text { rata }\end{array}$ & 31,48 & 53,37 & 31,48 \\
\hline
\end{tabular}


Tabel 4 Hasil pengukuran kelembaban

\begin{tabular}{rccccccc}
\hline Jenis tanah & $\begin{array}{c}\text { Hari } \\
\text { ke-1 }\end{array}$ & $\begin{array}{c}\text { Hari } \\
\text { ke-2 }\end{array}$ & $\begin{array}{c}\text { Hari } \\
\text { ke-3 }\end{array}$ & $\begin{array}{c}\text { Hari } \\
\text { ke-4 }\end{array}$ & $\begin{array}{c}\text { Hari } \\
\text { ke-5 }\end{array}$ & $\begin{array}{c}\text { Hari } \\
\text { ke-6 }\end{array}$ & $\begin{array}{c}\text { Hari } \\
\text { ke-7 }\end{array}$ \\
\hline Tanah Liat & 4,5 & 5,5 & 9.0 & 6,0 & 6,5 & $7 ., 0$ & 7,0 \\
\hline
\end{tabular}

Tabel 4 merupakan hasil pengukuran rata - rata kelembaban tanah dengan menggunakan alat pengukur kelembaban, dimana alat ukur langsung ditancapkan ke dalam tanah dan memiliki skala ukur 1 - 10. Pengukuran dilakukan pada semua jenis perlakuan baik itu untuk metode wenner ataupun metode driven rod. Bisa diliat pada tabel pada hari ke-3 kelembapan sangat tinggi dibandingkan hari lai hal ini dikarenakan pada subuh terjadi hujan yang mengakibatkan kelembapan menjadi tinggi.

\subsection{Pembahasan}

a. Sistem pentanahan dengan metode Driven rod

Berdasarkan data hasil pengukuran untuk driven rod yang terdapat pada tabel 2 dapat dibuat grafik rata-rata hasil pengukuran tahanan pentanahan. Pada grafik dibawah ini dapat diliat perbandingan ratarata nilai tahanan pentanahan baik untuk kedalaman 1 meter, 1,2 meter dan 1,5 meter.

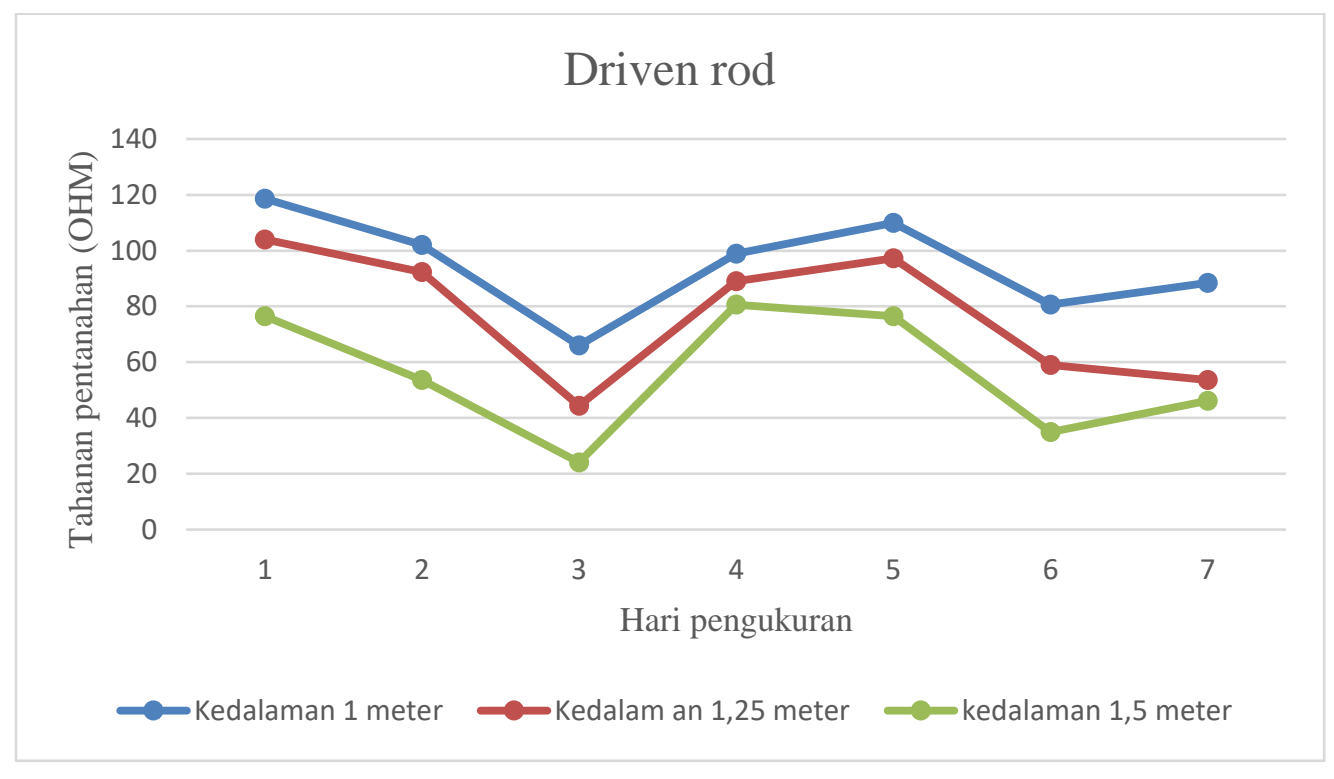

Gambar 5 Grafik pengaruh kedalaman elektrode metode Driven rod

Bedasarkan grafik pada Gambar 5 untuk kedalaman 1 meter terjadi penurunan tahanan pentanahan pada hari ke-3 hal ini juga berlaku untuk kedalaman 1,25 dan 1,5 meter, penurunan tahanan pentanahannya lumayan signifikan hal ini dipicu oleh terjadinya hujan pada subuh hari yang memicu kelembapan tanah pada area yang akan dilakukan pengukuran tahanan elektrode menjadi lebih lembab Pada grafik diatas dapat dijelaskan juga bahwa untuk nilai tahanan pentanahan yang terukur oleh alat earth tester untuk 
kedalaman elektrode pentanahan dengan kedalaman 1 meter berkisar dari 66,0 $\Omega$ - 188,6 $\Omega$ dengan ratarata nilai tahanan pentanahan yaitu 94,9 $\Omega$. Sedangkan untuk kedalaman elektrode pentanahan 1,25 meter didapatkan nilai tahanan pentanahan dari alat earth tester yaitu berkisar dari $104 \Omega-44,4 \Omega$ dengan nilai rata-rata nilai tahanan pentanahan yaitu 77,1 $\Omega$ dan untuk kedalaman 1,5 meter didapatkan nilai tahanan pentanahan berkisar dari 24,1 $\Omega$ - 80,6 $\Omega$ dengan nilai rata-rata nilai tahananan pentanahan yaitu $56 \Omega$. Hal ini sesuai dengan apa yang dinyatakan oleh (T.S Hutahuruk, 1991) bahwa kedalaman elektrode pentanahan akan berpengaruh terhadap nilai tahanan pentanahan dimana semakin dalam elektrode pentanahan ditanam maka nilai tahanan pentanahan juga akan semakin kecil.

\section{b. Sistem pentanahan dengan Metode Wenner}

Berdasarkan data hasil pengukuran untuk metode Wenner yang terdapat pada tabel 3 dapat dibuat grafik rata-rata hasil pengukuran tahanan pentanahan. Pada grafik dibawah ini dapat dilihat perbandingan rata-rata nilai tahanan pentanahan baik untuk kedalaman 1 meter, 1,2 meter dan 1,5 meter.

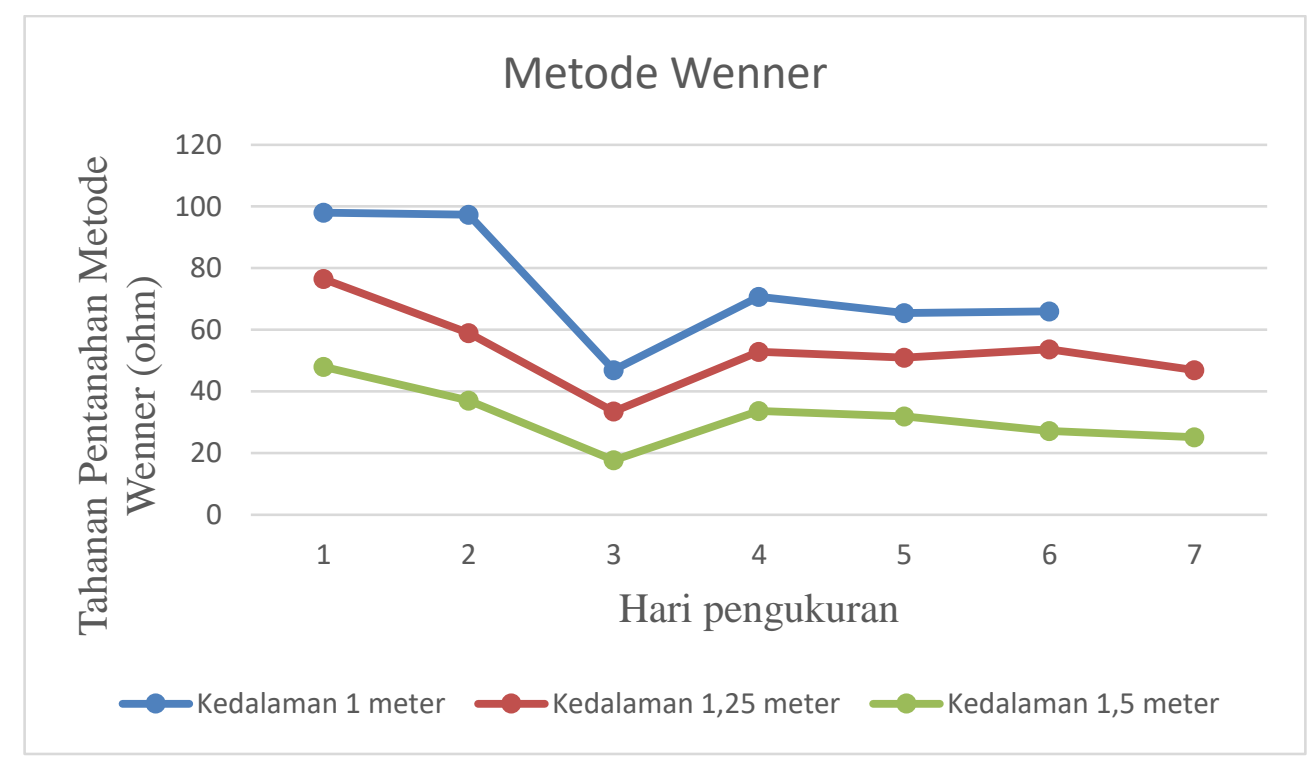

Gambar 6 Grafik pengaruh kedalaman elektrode metode Wenner

Pada Gambar 6 terlihat bahwa pengaruh kedalaman elektrode pentanahan cukup besar, yang mana penurunanan tahanann pentanahan signifikan terhadap penanaman batang elektrode pentanahan dimana semakin dalam batang elektrode ditanam maka nilai tahananan pentanahan akan semakin kecil.penurunan tahanan juga terjadi pada hari ketiga karena dipicu oleh hujan deras yang mengakibatkan tanah disekitar menjadi sangat lembab. Untuk sistem pentanahan Wenner sedikit berbeda dengan sistem pentanahan metode driven rod dimana untuk metode Wenner ini membutuhkan 2 batang elektrode utama dan 2 elektrodda bantu sedangkan untuk metode driven rod hanya membutuhkan 1 elektrode utama dan 2 elektrode bantu. Sesuai dengan tabel 4.2 diatas untuk nilai tahanan pentanahan yang didapatkan dari alat earth tester untuk kedalaman 1 meter yaitu berkisar antara $98 \Omega-47 \Omega$ dengan nilai rata -rata tahanan pentanahan yaitu $72,14 \Omega$. Sedangkan untuk kedalaman elektrode ` 1,25 meter didapat kan hasil pengukuran nilai tahanan pentanahan berkisar antara 76,5 $\Omega-33,5 \Omega$ dengan nilai rata-rata tahanan pentanahan yaitu 53,37 $\Omega$ dan untuk kedalamann elektrode $1,5 \Omega$ didapatkan hasil pengukuran dengan alat earth tester berkisar antara $48 \Omega$ - 17,7 $\Omega$ dengan nilai rata-rata tahanan pentanahan yaitu $31,48 \Omega$. 
c. Perbandingan sistem pentanahan dengan metode Driven rod dan Wenner

Setelah didapatkan data hasil pengukuran dengan alat earth tester baik itu untuk metode Driven rod dan metode Wenner seperti yang terlihat pada tabel 2 dan 3 maka dapat dilakukan perbandingan guna untuk mengetahui diantara kedua metode tersebut yang manakah yang menghasilkan nilai tahanan pentanahan yang kecil. Berikut grafik perbandingan nilai rata-rata tahanan pentanahan antara metode driven rod dan Wenner.

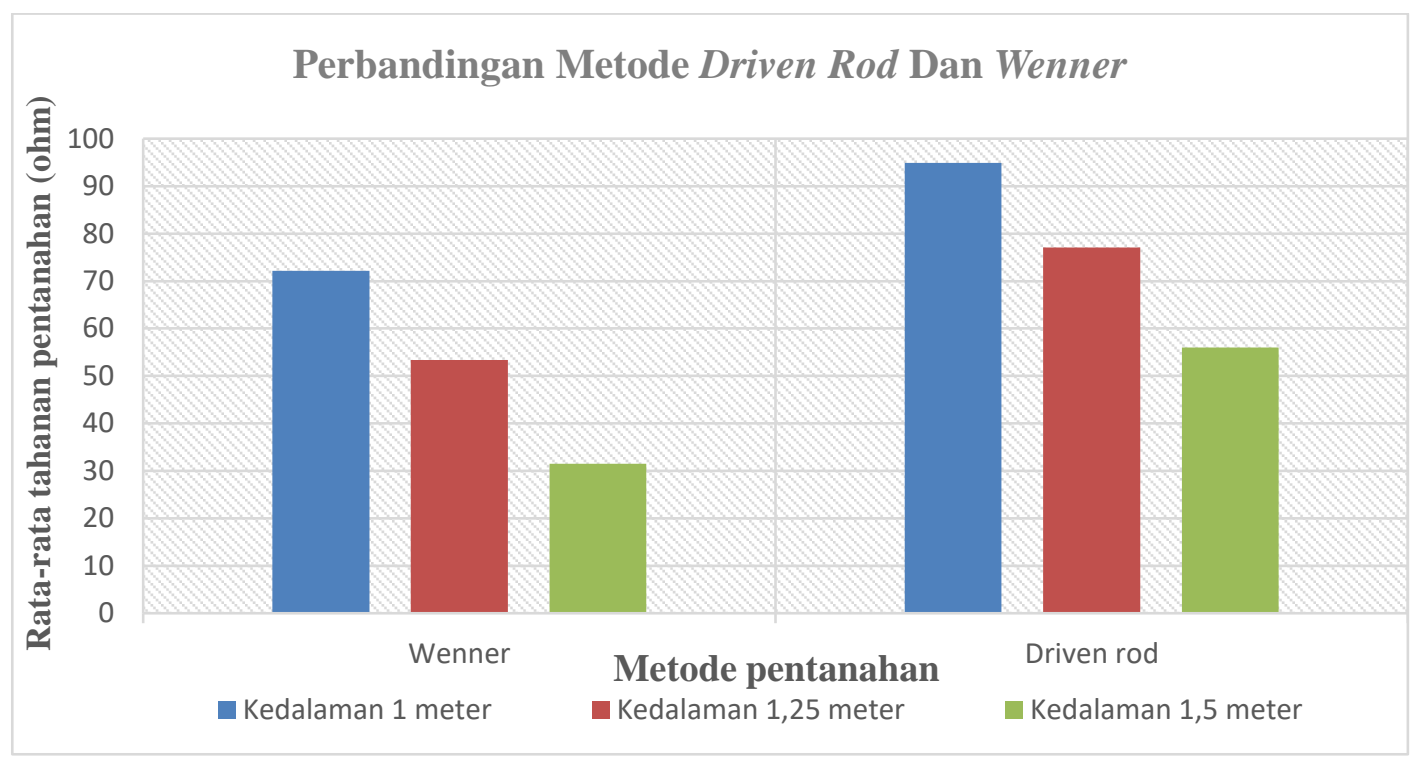

Gambar 7 Grafik Perbandingan nilai tahanan pentanahan

Pada gambar 5 dan gambar 6 terlihat bahwa untuk nilai tahananan pentanahan terjadi penurunan akibat dari pengaruh kedalaman elektrode dan kelembaban tanah. Selaian kedalaman dan kelembaban tanah ternyata metode sistem pentanahan juga ikut mempengaruhi nilai tahanan pentanahan seperti yang terlihat pada gambar 7 grafik menunjukkan bahwa untuk metode Wenner memiliki nilai tahanan pentanahan lebih kecil dibandingkan dengan metode driven rod, baik di kedalaman 1 meter maupun 1,5 meter. Untuk metode driven rod hanya memiliki tahanan pentanahan rata-rata berkisar antara 94,9 $\Omega$ - $56 \Omega$ memiliki nilai lebih besar jika dibandingkan dengan metode wenner yang memiliki rata-rata nilai tahanan pentanahan berkisar $72,14 \Omega .-331,48 \Omega$.

Sistem pentanahan metode Driven rod dan Wenner memiliki susunan/desain yang berbeda, dimana untuk metode driven rod hanaya memiliki 1 batang elektrode utama sedangkan untuk metode Wenner memiliki 2 batang elektrode utama yang dipasang secara paralel dengan kawat bc. Menurut (Hutahuruk, 1987) ada beberapa hal yang mempengaruhi tahanan pentanahan yaitu panjang/kedalaman elektrode pentanahan, diameter elektrode pentanahan, dan jumlah elektrode pentanahan. Hal inilah alasan mengapa untuk metode Wenner dapat memiliki tahanan pentanahan lebih kecil dibandingkan dengan metode Driven rod, dengan menambah elektrode penatanahan maka nilai tahanan pentanahan pun akan semakin kecil yang berarti jika makin banyak elektrode yang diparalelkan maka nilai tahanan pentanahan pun akan semakin kecil. Dari data hasil pengukuran dapat diketahui bahwa nilai tahanan pentanahan dengan menggunakan metode Wenner lebih baik dibandingkan dengan metode driven rod. 


\section{d. Hasil Perhitungan}

Tabel 5 merupakan hasil perhitungan dengan menggunakan persamaan yang telah dilakukan sebelumnya.

Tabel 5 Hasil perhitungan

\begin{tabular}{ccc}
\hline \multirow{2}{*}{ Keadalaman } & \multicolumn{2}{c}{ Perhitungan tahanan jenis tanah (ohm-m) } \\
\cline { 2 - 3 } & Driven rod & Wenner \\
\hline $\mathbf{1}$ meter & 113,5 & 2422.66 \\
\hline $\mathbf{1 , 2 5}$ meter & 112.2 & 1831,49 \\
\hline $\mathbf{1 , 5}$ meter & 93,86 & 1046 \\
\hline
\end{tabular}

Dari hasil perhitungan yang dilakukan menunjukkan bahwa semakin dalam elektrode pentanahan maka nilai tahanan jenis tanah pun akan semakin kecil. Untuk perhitungan metode driven rod didapatkan bahwa hasil pengukuran yang dilakukan langsung dilapangan sama hasilnya dengan hasil perhitungan, sedangkan untuk metode wenner hasil perhitungan yang didapatkan hasilnya sediki lebih besar dibandingkan dengan hasil pengukuran yang dilakukan dilapangan. Setelah dilakukan perhitungan ternyata terdapat selisih angka antara pengukuran yang dilakukan langsung dilapangan dengan hasil perhitungan, seperti yang terlihat pada tabel 5 .

\section{Kesimpulan}

Berdasarkan hasil pengujian yang sudah dilakukan dengan pengukuran secara langsung ataupun dengan melakukan perhitungan dan teori yang ada, maka dapat disimpulkan bahwa :

1. Untuk metode Driven rod didapatkan nilai tahanan pentanahan untuk kedalaman elektrode pentanahan yang ditanam dikedalaman 1 meter mendapat nilai tahanan pentanahan dengan rata-rata nilai tahanan pentanahan $94,9 \Omega, 1,25$ meter mendapatkan nilai rata-rata tahanan pentanahan sebesar $77,1 \Omega$, dan kedalaman 1,5 meter mendapatkan nilai rata-rata $56 \Omega$. Untuk metode Wenner didapatkan nilai rata-rata tahanan pentanahan untuk kedalaman 1 meter adalah $72,14 \Omega$ sedangkan untuk kedalaman elektrode pentanahan 1,25 meter didapatkan rata-rata nilai tahanan pentanahan 53,37 $\Omega$ dan kedalaman 1,5 meter didapatkan rata-rata nilai tahanan pentanahan 31,48. Berdasarkan data tersebut pengaruh kedalaman elektrode pentanahan cukup efektif untuk menurunkan tahanan pentanahan dijenis tanah liat.

2. Sedangkan untuk perbandingan antara Metode Driven rod dan Metode Wenner didapatkan data bahwa Metode Wenner lebih baik dalam menurunkan tahanan pentanahan dibandingkan dengan menggunakan metode Driven rod

Untuk penelitian selanjutnya mengenai sistem pentanahan sebaiknya dilakukan dengan memperhatikan saran sebagai berikut :

1. Untuk penelitian selanjutnya diharapkan menggunakan jenis elektrode yang berbeda seperti elektrode pita atau elektrode plat. 
2. Penelitian selanjutnya diharapkan menggunakan jenis tanah yang berbeda

3. Untuk penelitian selanjutnya diharapkan untuk mencoba membandingkan metode yang lain seperti metode driven rod tetapi dengan memparalelkan elektrode lebih dari 2 elektrode dengan metode schrumberger.

4. Untuk penelitian selanjutnya diharapkan untuk pengukuran metode Wenner menggunakan alat yang berbeda seperti multimeter atau meger.

\section{Daftar Pustaka}

[1] 80-2000, IEEE Std. (2000). IEEE guide for safety in AC Substation Grounding. IEEE Power Engineering Society.

[2] Dawalibi F.P., a. B. (1979). Parametric analysis pogf grounding systems. vol, Pass-99, no 4,pp. 334342.,Jan. 1994: IEEE Transaction on Power Apparatus and Systems.

[3] Hunia yang, J. Y. (2001). Determination Of Three-Layer Earth Model From Wenner Four-Probe Test Data. IEEE TRANSACTION ON MAGNETIC.

[4] Hutahuruk, d. (1987). sistem pentanahan jilid 1. jakarta: pusat perbukuan departemen pendidikan nasional.

[5] Hutahuruk, T. (1991). pengetahuan netral sistem tenaga dan pengetanahan peralatan. Erlangga.

[6] kusuma, D. s. (2016). Analisa perbedaan tahanan tanah di musim hujan dan kemarau pada pentanahan jaringan tegangan rendah didaerah bukit tinggi. vol.1 .

[7] M.H.Loke. (2000). Electrical imaging surveys for enviromental and enginnering studies : A practical guide to 2-D and 3-D surveys. Malaysia: Geotomo Software.

[8] M.W Telford, .. L. (1976). Apllied Geophysics. New York: Cambridge University Press.

[9] Nursyahida, F. (2015). Penelitian Eksperimen.

[10] PUIL. (2000). persyaratan umum instalasi listrik 2000 (puil 2000). jakarta: badan standardisasi nasional (bsn).

[11] Salamena, V. (2018). Pengaruh Kedalaman Elektrode Terhadap Pengukuran Tahanan Jenis Tanah,Pasir dan Air lLaut di Pulau Ambon Dengan Konfigurasi Wenner aAlfa. Jurnal Simetrik, VOL.8, NO.1.

[12] Sumardjati, P. (2008). Teknik Pemanfaatan Tenaga Listrik. jakarta.

[13] Sumardjiti. (2005). Teknik Listrik Pengukuran. jakarta: Bina Aksara.

[14] Waluyanti, S. (2008). Alat ukur dan teknik pengukuran jilid 2. bandung: Erlangga.

[15] Wenner, F. (1915). A Method Of Measuring Earth Resistivity. Dalam F. Wenner. Washington. 